\title{
Pustular Eruption
}

National Cancer Institute

\section{Source}

National Cancer Institute. Pustular Eruption. NCI Thesaurus. Code C111967.

A diffuse or generalized outbreak of numerous pustules. 